\title{
Gametophytic phase of three taxa of Anemia (Anemiaceae)
}

\section{Fase gametofítica de tres taxones de Anemia (Anemiaceae)}

\section{Acta Botanica Mexicana}

\author{
Cristina Janet Chambil’3 (iD, Olga Gladys Martínez',2 (iD
}

\begin{abstract}
:
Background and Aims: Anemiaceae has a single genus, Anemia, with 115 species distributed in the Neotropics, Africa, India, and islands in the Indian Ocean. The aim of this work is characterize living spores and gametophytic phase of three Anemia taxa from South America, little studied or with fragmentary studies, $A$. herzogii, $A$. tomentosa var. anthriscifolia and $A$. tomentosa var. tomentosa.

Methods: Gametophytes of the three taxa have been obtained through in vitro cultures of spores. The spores and gametophytes were studied with light and scanning electron microscopes. The germination pattern of the spores, the evolution of the gametophytic development and the sexual expression were described.

Key results: Filamentous gametophytes were formed by 4-20 cells, the adults were cordate, symmetrical or asymmetrical, bisexual and protandric, on their surfaces and margins clavate trichomes were observed. Gametangia corresponded to the leptosporangiate type. The dehiscence of antheridia was produced by a perforation in the opercular cell. Archegonia had necks with four to seven cells and four triangular cells at the distal end of the neck. Anemia herzogii showed branched trichomes on the gametophytes and later developed sporophytes.

Conclusions: Germination in all taxa corresponds to the Anemia-type and the gametophytic development to the Ceratopteris-type. Anemia herzogii is distinguished from the two varieties by the presence of branched trichomes exclusive of the gametophytic phase. The studied taxa are characterized by the morphology of gametophyte, type of trichomes and sexuality.
\end{abstract}

Key words: ferns, gametophytes, germination, spores, trichomes.

\section{Resumen:}

Antecedentes y Objetivos: Anemiaceae presenta un único género, Anemia, con 115 especies que se distribuyen en el Neotrópico, África, India e islas en el Océano Índico. El objetivo de este trabajo es caracterizar las esporas vivas y la fase gametofítica de tres taxones de Anemia sudamericanas, poco estudiadas o con estudios fragmentados, A. herzogii, A. tomentosa var. anthriscifolia y A. tomentosa var. tomentosa.

Métodos: Los gametofitos de los tres taxones han sido obtenidos a través de cultivos in vitro de las esporas. Las esporas y los gametofitos fueron estudiados a través del microscopio de luz y electrónico de barrido. Se describió el patrón de germinación de las esporas, evolución del desarrollo gametofítico y expresión sexual.

Resultados clave: Los gametofitos filamentosos estaban formados por 4-20 células, los adultos fueron cordados simétricos o asimétricos, bisexuales y protándricos, en sus superficies y márgenes se observaron tricomas clavados. Los gametangios corresponden al tipo leptosporangiado. La dehiscencia de los anteridios se produjo mediante una perforación en la célula opercular. Los arquegonios tenían cuellos con cuatro a siete células y cuatro células triangulares en el extremo distal del cuello. Anemia herzogii mostró tricomas ramificados sobre los gametofitos y más tarde desarrolló esporofitos. Conclusiones: La germinación en todos los taxones corresponde al tipo Anemia y el desarrollo gametofítico al tipo Ceratopteris. Anemia herzogii se distingue de las dos variedades por la presencia de tricomas ramificados exclusivos de la fase gametofítica. Los taxones estudiados se caracterizan por la morfología del gametofito, tipo de tricomas y sexualidad.

Palabras clave: esporas, gametofitos, germinación, helechos, tricomas.

\footnotetext{
'Universidad Nacional de Salta, Facultad de Ciencias Naturales, Av. Bolivia 5150, 4400 Salta, Argentina.

${ }^{2}$ Universidad Nacional de Salta, IBIGEO (Instituto de Bio y Geociencias del Noroeste Argentino, CONICET-UNSa), Facultad de Ciencias Naturales, Av. Bolivia 5150, 4400 Salta, Argentina.

${ }^{3}$ Author for correspondence: janet.unsa8@gmail.com
}

Received: November 1, 2019. Reviewed: January 29, 2020.

Accepted by Rosario Redonda Martínez: July 1, 2020. Published Online first: July 9, 2020.

Published: Acta Botanica Mexicana 127 (2020).
To cite as: Chambi, C. J. and O. G. Martínez. 2020. Gametophytic phase of three taxa of Anemia (Anemiaceae). Acta Botanica Mexicana 127: e1631. DOI: 10.21829/abm127.2020.1631

\footnotetext{
(c) (1) \$ This is an open access article under the Cre(c) (1) \$ 5 ative Commons 4.0 Attribution-Non commercial Licence (CC BY-NC 4.0 International).
}

e-ISSN: 2448-7589 


\section{Introduction}

Anemiaceae is a monophyletic family (Labiak et al., 2015) that together with Lygodiaceae and Schizaeaceae constitute the Schizaeales, a different clade from the remaining leptosporangiate ferns (Smith et al., 2006; PPG I, 2016). This family has a single genus Anemia Sw., with 115 species that grow, in the Neotropics, Africa, India, and islands in the Indian Ocean (Smith et al., 2006; Mickel, 2016; Smith and Kessler, 2017).

The species of the genus Anemia are characterized by having sessile, subglobose or ovoid sporangia with an apical annulus, and trilete ornamented spores, tetrahedral to globose (De la Sota and Morbelli, 1987; Tryon and Lugardon, 1991). According to the spore ornamentation, Ramos Giacosa et al. (2012) proposed two morphological types for the species that grow in Argentina: Anemia australis-type, with ridges, and Anemia herzogii-type, with ridges and bacula. Irregular shapes were mentioned by Mickel (1962), De la Sota and Mickel (1968), and Ramos Giacosa (2014).

Regarding the gametophytic development, Nayar and Kaur (1971) classified the spore germination of Anemiaceae as Anemia-type and the gametophytic development as Ceratopteris-type. The development of the meristem was described by Pray (1971) in A. colimensis Mickel, and by Takahashi et al. (2012) in Anemia phyllitidis (L.) Sw.

Atkinson (1962) and Nayar and Kaur (1971) identified the Anemiaceae gametophytes as asymmetric cordate, raised on the substrate, bisexual, usually with simple trichomes, glandular or eglandular not secretory. Other studies carried out by Pray (1971), Nester and Schedlbauer (1981), Nester (1985), Grill (1988), Hernández-Solano (2004), and Escamilla-Aquino et al. (2008) pointed out similar features for the different species of Anemia. De la Sota and Morbelli (1987) described four types of adult laminar gametophytes for American species: filamentous, filamentous with an axial or pseudo-axial shape, tuberous axial, and cordate-thalloid type.

Experimental research carried out on gametophytes, of A. hirsuta (L.) Sw., A. phyllitidis, A. mexicana Klotzsch, shows that they produce antheridiogens that promote the development of antheridia in young gametophytes even in the darkness (Näf, 1969; Näf et al., 1975; Nester et al., 1987; Yamane, 1998). Nester and Coolbaugh (1986) recorded for A. mexicana and $A$. phyllitidis, $\mathrm{pH} 6$ and eight light hours as optimal conditions to induce spore germination. This kind of information allows planning for Anemia spore culture to produce sporeling with ornamental aims or biological and conservation interest. For instance, Pinto et al. (2013) mention that $A$. tomentosa (Sav.) Sw. var. anthriscifolia (Schrad.) Mickel produces an essential oil with antibacterial activity apart from its potential value as ornamental.

Within the framework of biology and gametophytic diversity of ferns, we characterize living spores and gametophytic phase of three Anemia taxa, little studied or with fragmentary studies, $A$. herzogii Rosenst., $A$. tomentosa var. anthriscifolia and A. tomentosa (Sav.) Sw. var. tomentosa, in order to increase the knowledge on the gametophytic phase of this fern genus for future taxonomic studies.

\section{Materials and Methods}

The material for this study comes from samples collected in natural environments of northwestern Argentina. Reference samples were deposited in the MCNS Herbarium (Thiers, 2018 continuously updated), Universidad Nacional de Salta, Argentina.

\section{Studied material}

Anemia herzogii: ARGENTINA. Salta, Orán, Río Blanquito, $900 \mathrm{~m}, 23^{\circ} 06.8^{\prime} \mathrm{S}, 64^{\circ} 29.3^{\prime} \mathrm{W}, 6 . X \mathrm{II} .2011$, C. J. Chambi 441 (MCNS).

Anemia tomentosa var. anthriscifolia: ARGENTINA. Salta, La Caldera, $1500 \mathrm{~m}, 25^{\circ} 30^{\prime} \mathrm{S}, 6^{\circ} 20.6^{\prime} \mathrm{W}, 2.1 \mathrm{l} .2011, \mathrm{O}$. G. Martínez 2102 (MCNS).

Anemia tomentosa var. tomentosa: ARGENTINA. Salta, Rosario de la Frontera, $850 \mathrm{~m}, 25^{\circ} 50.1^{\prime} \mathrm{S}, 64^{\circ} 55.5^{\prime} \mathrm{W}$, 27.VI.2011, O. G. Martínez 2146 (MCNS).

Fertile pinnae of each individual were kept in individually labeled paper bags. They were dried for seven days at room temperature to favor sporangia opening and subsequent spore liberation. For the spore analyses, the specimens were studied without chemical treatment, using light (LM) (Zeiss Standart Model 16, Carl Zeiss, Göttingen, Germany) and scanning electron microscopy (SEM) (JEOL JSM 6480 LV, JEOL, Tokyo, Japan) at the Facultad de Ciencias Naturales, Universidad Nacional de Salta, Argentina and a SEM at the Laboratorio de Microscopia Electrónica de Barrido y 
Microanálisis (LASEM), Universidad Nacional de Salta, Argentina. A total of 30 spores were measured for each taxon under a LM, the size of the equatorial and the polar diameter is indicated on average, and the lowest and highest values in parentheses (Table 1). For SEM studies the spores were mounted directly on a double-sided tape and coated with gold.

For sowing spores with 10 days of storage were used. Before sowing the material was sieved with a metallic mesh (pores $120 \mu \mathrm{m}$ diameter) to eliminate traces of leaves and sporangia. Spores were sterilized with $10 \%$ sodium hypochlorite for five minutes, rinsed with sterilized water, and sown in Petri dishes ( $5 \mathrm{~cm}$ diameter), with Dyer medium (Dyer, 1979) gelled with agar $10 \mathrm{~g} / \mathrm{l}$. A total of 30 Petri dishes were sown, 10 replicas for each taxon. The cultures were kept in growth chambers (BS610, Bioamerican Science, Córdoba, Argentina) at $21 \pm 3{ }^{\circ} \mathrm{C}$ with periods of 12 hours of light. The observations were made periodically, the first week every day and from the second week, once every seven days for 10 weeks. In each record, 10 fields were evaluated. For evaluating the germination percentage, we considered as viable spores those with cellular content, and no viable spores those that were collapsed and without celIular content.

Gametophyte development was observed for two years. For gametophyte measurements 10 samples were considered for each taxon, the sizes were expressed as means of length and standard deviation. Spores and gametophytes extracted for observation were removed to avoid contamination.

The gametophytes were fixed in acetocarmine choral hydrate (Edwards and Miller, 1972) for the observations with LM, and with $2.5 \%$ glutaraldehyde in phosphate buffer and dehydrated in a graded ethanol series for SEM studies. The photographs of the spores and gametophytes were taken with an optical microscope and a SEM.

\section{Results}

\section{Spores}

Living spores from the three studied taxa are dark brown, trilete, tetrahedral-globose shaped, with prominent angles and ornamented with ridges, with or without bacula (Fig. $1)$. The measurements of equatorial and polar diameter corresponding to each taxon are shown in Table 1. In A. tomentosa var. tomentosa, ca. $30 \%$ of irregular spores with variable dimensions, atypical shapes of monoletes, and spores grouped in diades were recorded. The three taxa showed $2 \%$ of spores without cellular content.

\section{Germination}

Spore germination in all taxa begins 4-5 days after sowing, as in A. herzogii (Fig. 2A). The first cell divides in two equal cells, one of which remains inactive, whereas the other, divides in two cells of different dimensions. The largest one will result in the gametophyte and the other one in the rhizoid.

In the three taxa germination increases gradually during the first ten weeks. The highest germination percentage is recorded in $A$. tomentosa var. anthriscifolia of $98 \%$ germinated spores out of a total of 709 spores, in $A$. herzogii $78 \%$ out of a total of 1302 spores and the lowest percentage in $A$. tomentosa var. tomentosa with $72 \%$ germinated spores out of a total of 1073 spores.

Table 1: Comparative analysis of spores of Anemia herzogii Rosenst., A. tomentosa (Sav.) Sw. var. anthriscifolia (Schrad.) Mickel and A. tomentosa (Sav.) Sw. var. tomentosa.

\begin{tabular}{|c|c|c|c|}
\hline Taxa & Ornamentation & $\begin{array}{l}\text { Equatorial } \\
\text { diameter }(\mu \mathrm{m})\end{array}$ & $\begin{array}{l}\text { Polar diameter } \\
(\mu \mathrm{m})\end{array}$ \\
\hline Anemia herzogii Rosenst. & $\begin{array}{l}\text { narrow parallel ridges with bacula } \\
\text { separated by ample depressions }\end{array}$ & $(53) 66(78)$ & $(42) 57(69)$ \\
\hline A. tomentosa (Sav.) Sw. var. anthriscifolia (Schrad.) Mickel & ample parallel ridges separated by & $(76) 88(94)$ & $(68) 76(82)$ \\
\hline A. tomentosa (Sav.) Sw. var. tomentosa & narrow depressions & $(75) 100(113)$ & $(69) 80(95)$ \\
\hline
\end{tabular}



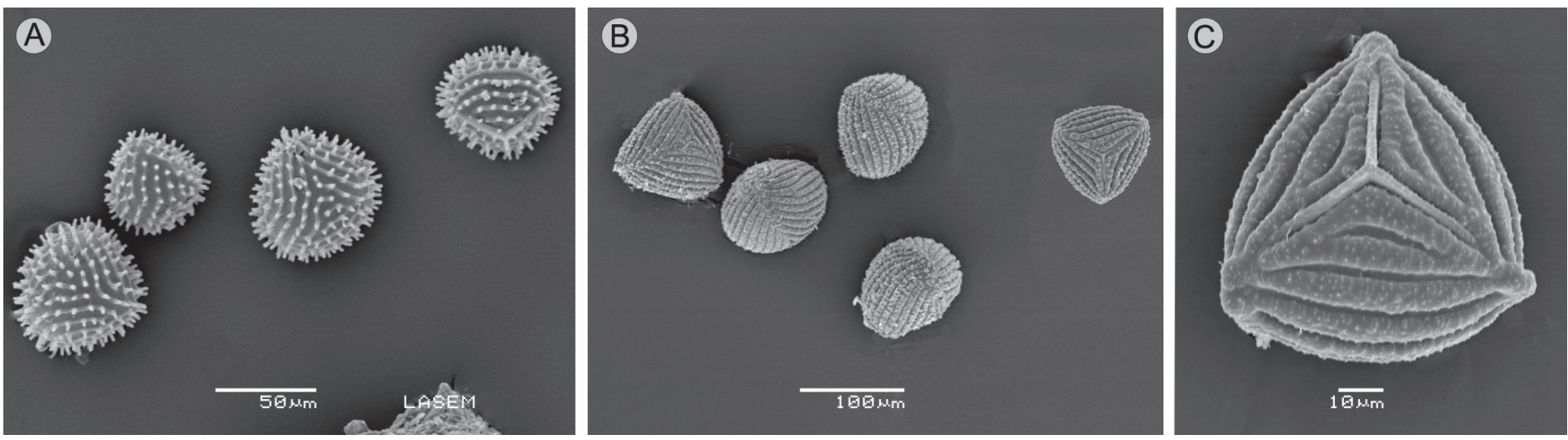

Figure 1: Spores. A. spores of Anemia herzogii Rosenst., two spores in distal view (left and middle) and one in equatorial view (right); B. spores of Anemia tomentosa (Sav.) Sw. var. tomentosa, one spore in distal view (left), three in equatorial view (middle) and one in proximal view (right); C. spore of Anemia tomentosa (Sav.) Sw. var. anthriscifolia (Schrad.) Mickel in proximal view.

\section{Filamentous gametophytes}

The filamentous gametophytes have variable length, from 4-20 cells, germinated between 5-10 days after sowing (Fig. 2B). In Anemia tomentosa var. tomentosa, they are short, with 4-10 cells with an average length of 0.59 $\pm 0.26 \mathrm{~mm}$ (Fig. 2C). In A. herzogii and A. tomentosa var. anthriscifolia, they are long, with more than seven cells. In Anemia herzogii they consist of $12-18$ cells with an average length of $1.34 \pm 0.20$ $\mathrm{mm}$ (Fig. 2D) while in A. tomentosa var. anthriscifolia they consist of 7-20 cells with an average length $1.28 \pm 0.23 \mathrm{~mm}$. One to three rhizoids are found in cells near the spore. The cells of filamentous gametophytes are anisodiametric of $32 \pm 7 \mu \mathrm{m}$ and $132 \pm 34 \mu \mathrm{m}$ length, respectively.

\section{Laminar gametophytes}

The laminar phase began between 10-15 days after the spores' germination with the multiplication of the filamentous gametophytes distal cells. In the first stages of the laminar phase, the gametophytes are largely spatulate with marginal meristem (Figs. 2E-I). Twenty days after sowing, the length of gametophytes of $A$. herzogii have an average size of $1.95 \pm 0.23 \mathrm{~mm}$ (Fig. $2 \mathrm{E}$ ), while in A. tomentosa var. tomentosa they measure $1.36 \pm 0.43 \mathrm{~mm}$ (Fig. $2 \mathrm{~F}$ ) and in A. tomentosa var. anthriscifolia $2.45 \pm 0.57 \mathrm{~mm}$ (Fig. $2 \mathrm{G}$ ). After the meristematic region becomes apical, cordate or spatulated adult gametophytes are formed, 40-60 days after germination.

In the three taxa, the laminar gametophytes have few clavate trichomes, 1-2-cellular, 20-30 $\mu \mathrm{m}$ long, on both mar- gins and surface (Figs. 3A, B). Generally, marginal trichomes are curved, directed to the notch. The trichomes are formed 20 days after the sowing of the spores, when the notch starts being noticed. Also, in $A$. herzogii, branched trichomes 50-60 $\mu \mathrm{m}$ long are formed on the midrib between the gametangia, consisting of one basal short cell and two different distal cells, a short papillate cell and an eglandular elongate cell (Fig. 3C).

\section{Sexuality}

The gametophytes of $A$. herzogii and the two varieties of $A$. tomentosa are bisexual and protandric. Gametangia are of the common leptosporangiate type (Nayar and Kaur, 1971), appearing only on the abaxial surface of the gametophyte with archegonia near the notch, and many antheridia distributed mainly towards the base, mixed with rhizoids. Antheridia appeared 50 days after sowing in $A$. herzogii and $A$. tomentosa var. anthriscifolia, and after 90 days in var. tomentosa. The dehiscence of antheridia is produced in every case through perforation of the opercular cell (Fig. 3D). Archegonia originated under the notch after 60 days in $A$. herzogii, and after 100 days in the two varieties of $A$. tomentosa. The neck of the archegonia is curved away from the notched end of the gametophyte, and it is composed of four rows each with four cells long in A. tomentosa var. tomentosa (Fig. 3E), four to five cells in A. tomentosa var. anthriscifolia (Fig. 3F) and five to seven cells in $A$. herzogii (Fig. $3 \mathrm{C}$ ), the mouth consists of four triangular cells. The adult gametophyte characteristics of the taxa analyzed are summarized in Table 2. 

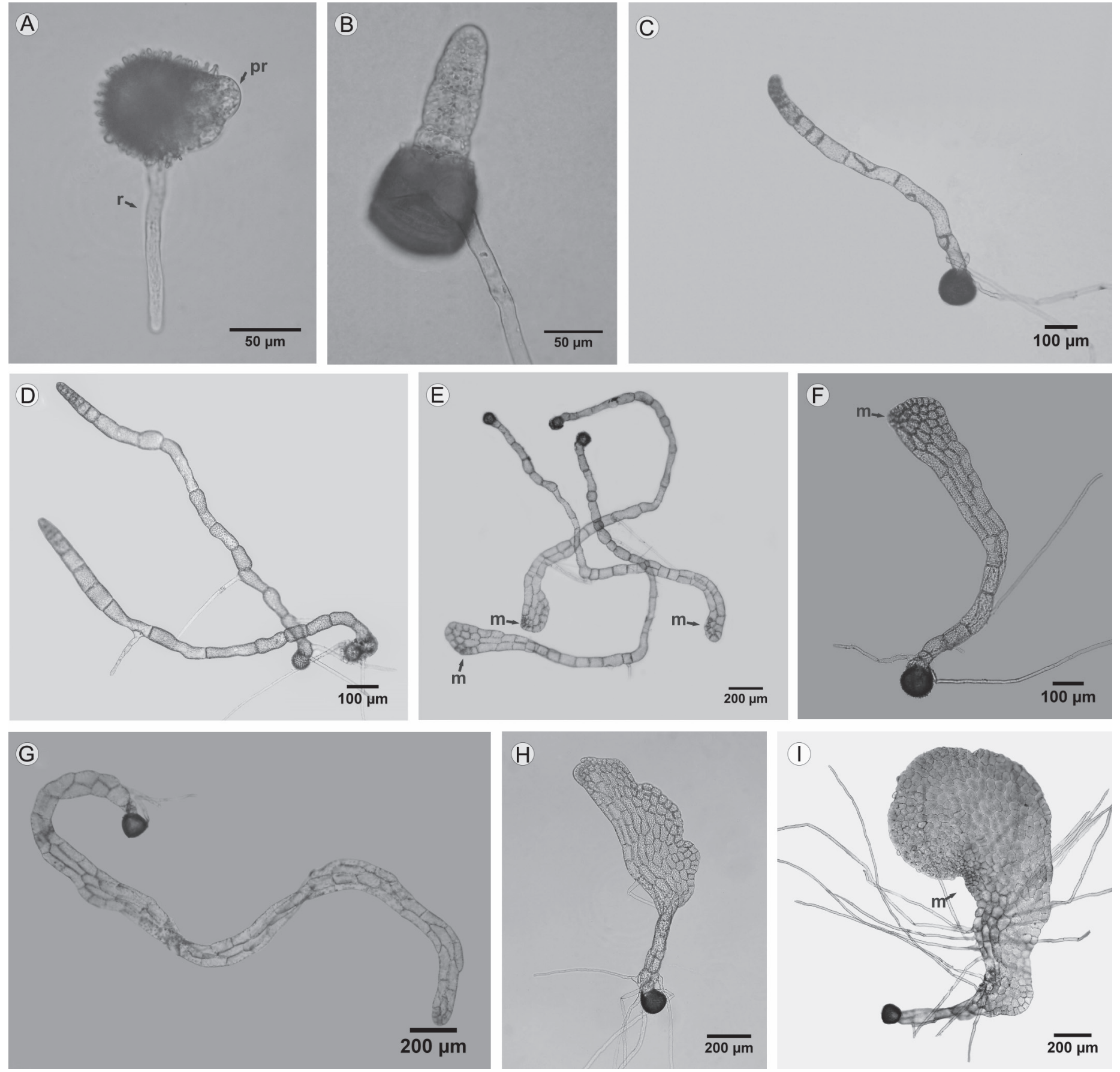

Figure 2: A. spore germination of Anemia herzogii Rosenst., B-D. filamentous gametophytes: B. Anemia tomentosa (Sav.) Sw. var. anthriscifolia (Schrad.) Mickel (5 days); C. Anemia tomentosa (Sav.) Sw. var. tomentosa (10 days); D. Anemia herzogii Rosenst. (10 days); E-H. laminar gametophytes of spatulate shape; E. Anemia herzogii Rosenst. (14 days); F. Anemia tomentosa (Sav.) Sw. var. tomentosa (20 days); G. Anemia tomentosa (Sav.) Sw. var. anthriscifolia (Schrad.) Mickel (20 days); H. Anemia tomentosa (Sav.) Sw. var. tomentosa (30 days); I. young laminar gametophyte of Anemia tomentosa (Sav.) Sw. var. tomentosa (50 days). (m) meristem; (pr) prothallus; ( $\mathrm{r}$ ) rhizoid.

\section{Young sporophytes}

The formation of sporophytes is only evident in A. herzogii after 180 days (Fig. 4A). The young sporophytes have spatulate laminae with entire margin, hypostomatic, with desmocytic and pericytic stomata, and dichotomous venation (Fig. 4B), with eglandular and clavate trichomes similar as those present in the gametophytes (Fig. 4C). 

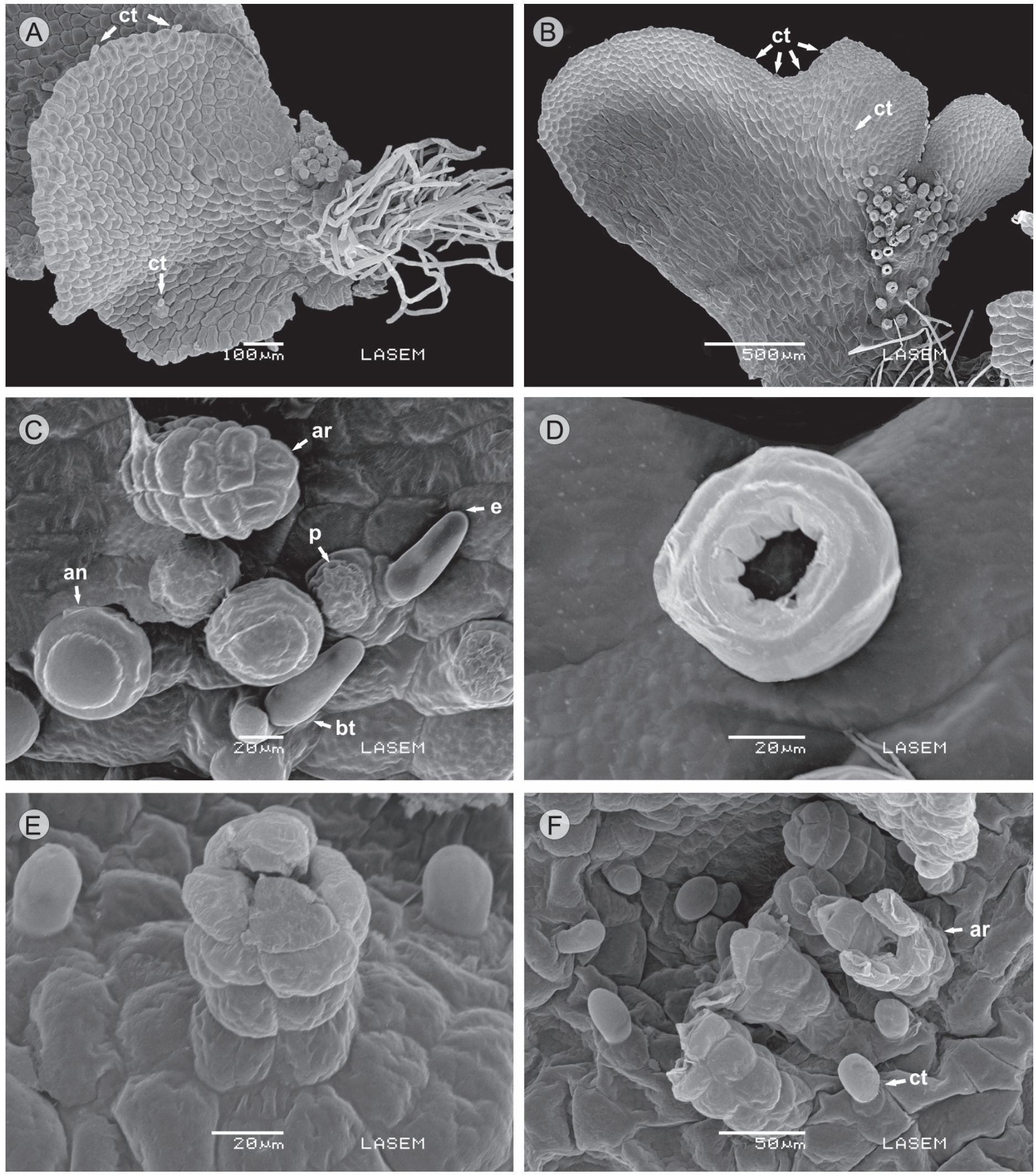

Figure 3: Microphotographs of adult gametophytes. A. Anemia tomentosa (Sav.) Sw. var. tomentosa with clavate trichomes; B. Anemia herzogii Rosenst. with clavate trichomes; C. Anemia herzogii Rosenst. showing branched trichomes, antheridia and archegonia neck; D. Anemia herzogii Rosenst. with detail of antheridium with perforated opercular cell; E. Anemia tomentosa (Sav.) Sw. var. tomentosa archegonium with four cells; F. Anemia tomentosa (Sav.) Sw. var. anthriscifolia (Schrad.) Mickel showing mature archegonia with open neck and superficial trichomes. (ct) clavate trichomes; (bt) branched trichomes; (ar) archegonium; (an) antheridium; (p) papillate cell; (e) eglandular cell. 
Table 2: Morphological characters of the gametophytes of Anemia herzogii Rosenst., A. tomentosa (Sav.) Sw. var. anthriscifolia (Schrad.) Mickel and A. tomentosa (Sav.) Sw. var. tomentosa.

\begin{tabular}{|c|c|c|c|c|c|}
\hline Taxa & $\begin{array}{c}\text { Adult } \\
\text { gametophyte }\end{array}$ & Trichomes & Sexuality & Archegonial neck & $\begin{array}{c}\text { Length adult } \\
\text { gametophytes } \\
(\mathrm{mm})\end{array}$ \\
\hline A. herzogii Rosenst. & $\begin{array}{l}\text { asymmetrical } \\
\text { cordate }\end{array}$ & $\begin{array}{l}\text { branched } \\
\text { trichomes }\end{array}$ & bisexual & 5 to 7 cells & $2.66 \pm 0.62$ \\
\hline $\begin{array}{l}\text { A. tomentosa (Sav.) Sw. var. anthriscifolia } \\
\text { (Schrad) Mickel }\end{array}$ & $\begin{array}{c}\text { symmetrical } \\
\text { cordate }\end{array}$ & clavate & bisexual & 4 to 5 cells & $2.58 \pm 0.45$ \\
\hline A. tomentosa (Sav.) Sw. var. tomentosa & $\begin{array}{l}\text { asymmetrical } \\
\text { cordate }\end{array}$ & clavate & bisexual & 4 cells & $1.84 \pm 0.21$ \\
\hline
\end{tabular}
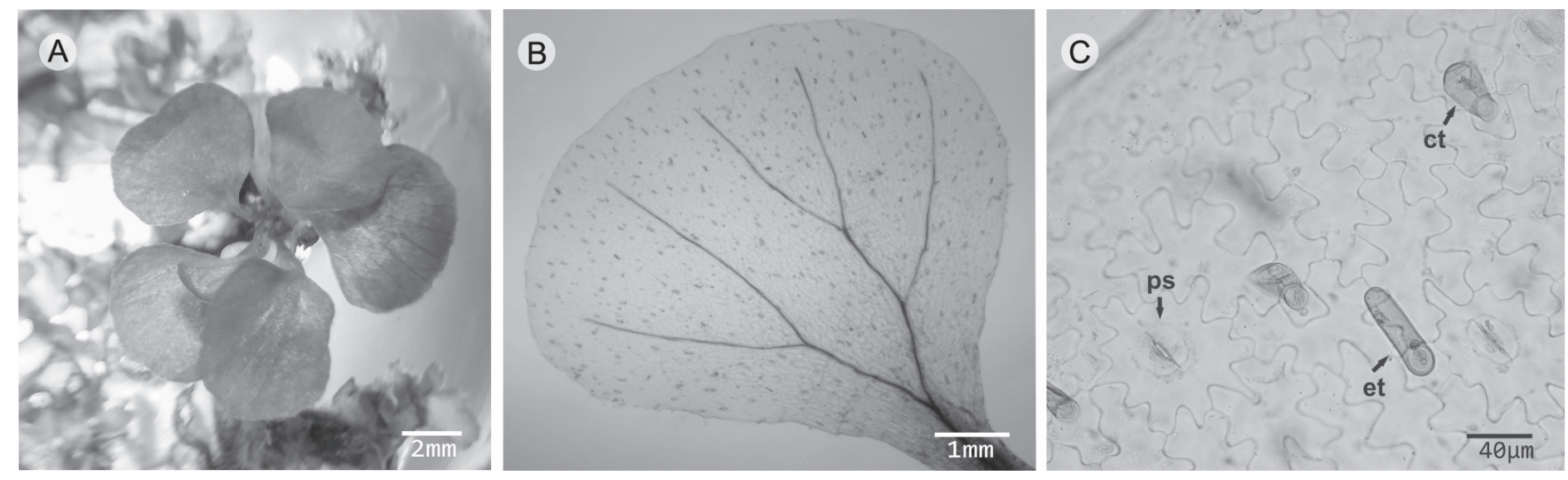

Figure 4: Young sporophyte of Anemia herzogii Rosenst. A. young sporophyte growing in Dyer medium; B. lamina with dichotomous venation; C. detail of eglandular and clavate trichomes and pericytic stomata. (et) eglandular trichome; (ct) clavate trichome; (ps) pericytic stomata.

\section{Discussion}

The palynological features, such as shape, dimension, ornament and color of the spores in Anemia herzogii, A. tomentosa var. anthriscifolia and $A$. tomentosa var. tomentosa, recorded in this work, are consistent with the descriptions by Tryon and Lugardon (1991), Ramos Giacosa et al. (2012) and Labiak et al. (2015). De la Sota and Mickel (1968) and Ramos Giacosa (2014) cited irregular shapes and dimensions in the spores of both varieties of $A$. tomentosa, however, these irregularities were only found in var. anthriscifolia. Mickel (1962), attributed the irregular shapes of the spores of this variety to hexaploidy.

The germination of spores, in the three taxa, corresponds to the Anemia-type, described for other species of this genus by Atkinson (1962), Nayar and Kaur (1971),
Raghavan and Huckaby (1980), Nester and Schedlbauer (1981), Nester and Coolbaugh (1986) and Takahashi et al. (2012). Several authors mentioned that the ability to germinate depends on environmental factors that can influence the process, such as light, $\mathrm{pH}$ and hormones (Nester and Coolbaugh, 1986; Miller, 1968; Von Aderkas and Cutrer, 1983). Raghavan and Huckaby (1980) ensured that spore germination of Anemia hirsuta, A. munchii Christ and $A$. phyllitidis starts within 24 hours with the incidence of red light. In natural conditions, it happens within 3-4 days in A. mexicana (Nester and Schedlbauer, 1981), and within 30 days in $A$. munchii (Escamilla-Aquino et al., 2008). The spores of the three taxa studied here, germinated 4-5 days after sowing with high germination percentages of over $70 \%$. 
The number of cells that constitute the filamentous gametophytes of Anemia tomentosa var. tomentosa does not exceed 10; in the case of $A$. herzogii and $A$. tomentosa var. anthriscifolia this may be up to 20 . In this phase gametophytes match with the one recorded in $A$. munchii, in which the filaments have up to 20 cells (Escamilla-Aquino et al., 2008) and A. phyllitidis with filaments from three to seven cells (Takahashi et al., 2012).

The development of the gametophytes' lamina corresponds to the Ceratopteris-type pattern proposed by Nayar and Kaur (1971); a morphological pattern shared with many genera in the large Pteridaceae family (Martínez, 2010; Martínez et al., 2017). The three taxa studied developed a lateral marginal meristem on one side of the laminar gametophytes, this which also described by previous authors (Atkinson, 1962; Nayar and Kaur, 1971; Nester and Schedlbauer, 1981; Raghavan, 1989; Escamilla-Aquino et al., 2008). Pray (1971) described that A. colimensis a developed lateral marginal meristem on both sides of the laminar gametophyte, although one of them remains without activity. The laminar phase is also characterized by the development of clavate trichomes in the three studied taxa, which were observed in other species of Anemia as well (Nayar and Kaur, 1971; Nester and Schedlbauer, 1981; Escamilla-Aquino et al., 2008). However, the branched trichomes of $A$. herzogii have not been previously described for gametophytes or sporophytes of Anemia; similar structures were mentioned by Nayar and Kaur (1971) for Ctenopteris suspensa (L.) Copel. (= Lellingeria suspensa (L.) A.R. Sm. and R.C. Moran), a Polypodiaceae.

The shape of adult gametophytes is principally cordate, symmetric and asymmetric. In Anemia gametophytes were reported as bisexual and unisexual (Atkinson, 1962; Mickel, 1962; Pray, 1971; Reynolds, 1979; Nester and Schedlbauer, 1981; Nester, 1985; Escamilla-Aquino et al., 2008; Takahashi et al., 2012), in this study bisexuality prevails.

The structure of gametangia, antheridia and archegonia corresponds partially to those cited for other Anemia species by Atkinson (1962), Nayar and Kaur (1971) and Nester (1985). The authors mentioned that the dehiscence of antheridia is produced by the partial or complete detachment of the opercular cell. In this case, it was observed that in $A$. herzogii and in the two varieties of $A$. tomentosa it is produced by the perforation itself.

The archegonia in the three taxa studied have the same location and quantity of cells, they do not have trichomes on the necks. Nevertheless, Nester (1985) mentioned the presence of unicellular trichomes in A. mexicana, such as marginal trichomes observed in gametophytes of these species.

In young sporophytes of $A$. herzogii, the laminae have simple, eglandular and clavate trichomes, as the ones observed in the adult sporophytes of $A$. australis (Mickel) M. Kessler and A.R. Sm. (Luján et al., 2011). The type of stomata observed in the studied species coincide with those of Luján et al. (2011).

The molecular phylogenetic studies from Labiak et al. (2015) determine that Anemia is a monophyletic genus, and they distinguish, among others, the Tomentosae clade (including $A$. tomentosa var. tomentosa and $A$. tomentosa var. anthriscifolia) and the Phyllitidis clade (including $A$. herzogii and A. phyllitidis), both differentiated by the spores ornamentation. The gametophytic contribution obtained in this study differentiates the varieties of $A$. tomentosa by its morphology of young laminar gametophyte, and $A$. herzogii by having branched trichomes exclusive of the gametophytic phase.

\section{Author contributions}

CJC acquired the data and processing of samples with the help of OGM. Both authors analyzed and interpreted the results, wrote, read and approved the final manuscript.

\section{Funding}

This study was financed by the Consejo de Investigación (Proyecto 2344/0) of the Universidad Nacional de Salta.

\section{Acknowledgments}

The authors thank Paula Narváez for the English revision, the editor and two anonymous reviewers for their constructive comments, which helped us to improve the manuscript, and Silvia Blanco for the assistance provided during the Scanning Electron Microscopy service at the LASEM-UNSa. 


\section{Literature cited}

Atkinson, L. R. 1962. The Schizaeaceae: The gametophyte of Anemia. Phytomorphology 12: 264-288.

De la Sota, E. R. and J. T. Mickel. 1968. Sinopsis de las especies argentinas del género Anemia Swartz (Schizaeaceae). Revista del Museo de La Plata, Nueva serie Sección Botánica 11(61): 133-152.

De la Sota, E. R. and M. A. Morbelli. 1987. Schizaeales. Phytomorphology 37(4): 365-393.

Dyer, A. F. 1979. The culture of fern gametophytes for experimental investigation. In: Dyer, A. F. (ed.). The experimental biology of ferns. Academic Press. London, England. Pp. 254-305.

Edwards, M. E. and J. H. Miller. 1972. Growth regulation by ethylene in fern gametophytes III. Inhibition of spore germination. American Journal of Botany 59(5): 458-465. DOI: https://doi.org/10.1002/j.1537-2197.1972.tb10117.x

Escamilla-Aquino, A. M., M. L. Arreguín-Sánchez and R. Fernández-Nava. 2008. Ciclos Biológicos de Anemia munchi Christ (Schizaeaceae-Pteridophyta) y Pityrogramma calomelanos (L.) Link (Adiantaceae-Pteridophyta). Polibotánica 26: 101-111.

Grill, R. 1988. Photocontrol of Gibberellin-induced precocious antheridium formation in the fern Anemia phyllitidis L. Sw. Journal of Plant Physiology 133(3): 381-384. DOI: https:// doi.org/10.1016/S0176-1617(88)80222-0

Hernández-Solano, J. 2004. Descripción de las fases del ciclo de vida de Adiantum concinnum Humb. et Blonpl. ex Willd. (Adiantaceae-Pteridophyta y Anemia adiantifolia (Schizaceae-Pteridophyta). Tesis de licenciatura. Escuela Nacional de Ciencias Biológicas, Instituto Politécnico Nacional. Cd. Mx., México. 52 pp.

Labiak, P. H., J. T. Mickel and J. G. Hanks. 2015. Molecular phylogeny and character evolution of Anemiaceae (Schizaeales). Taxon 64(6): 1141-1158. DOI: https://doi. org/10.12705/646.3

Luján, M. C., R. Morero and G. E. Barboza. 2011. Estudios epidérmicos en helechos y licófitas medicinales de la Provincia de Córdoba, Argentina. Hoehnea 38(4): 609-659. DOI: https:// doi.org/10.1590/S2236-89062011000400007

Martínez, O. G. 2010. Gametófitos y esporófitos jóvenes de cuatro especies naturalizadas de Pteris (Pteridaceae) en América. Revista de Biología Tropical 58(1): 81-92. DOI: https://doi.org/10.15517/rbt.v58i1.5196
Martínez, O. G., M. A. Hernández and M. M. Ponce. 2017. Reproductive expression of cheilanthoid ferns (Pteridaceae) from South America. Flora 236-237: 126-131. DOI: https:// doi.org/10.1016/j.flora.2017.10.003

Mickel, J. T. 1962. A monographic study of the fern genus Anemia, subgenus Coptophyllum. Iowa State College Journal of Science 36: 349-482.

Mickel, J. T. 2016. Anemia (Anemiaceae). Flora Neotropica Monograph 118: 1-182.

Miller, J. H. 1968. Fern gametophytes as experimental material. The Botanical Review 34: 361-440. DOI: https://doi. org/10.1007/BF02859133

Näf, U. 1969. On the control of antheridium formation in ferns. In: Gunckel, J. E. (ed.). Current Topics in Plant Science. Academic Press. New York, USA. Pp. 97-116.

Näf, U., K. Nakanishi and M. Endo. 1975. On the physiology and chemistry of fern antheridiogens. The Botanical Review 41(3): 315-359. DOI: https://doi.org/10.1007/BF02860840

Nayar, B. K. and S. Kaur. 1971. Gametophytes of homosporous ferns. The Botanical Review 37: 330-331. DOI: https://doi. org/10.1007/BF02859157

Nester, J. E. 1985. Scanning Electron Microscopy of antheridia and archegonia of Anemia mexicana Klotzsch. American Journal of Botany 72(5): 777-780. DOI: https://doi. org/10.2307/2443692

Nester, J. E. and R. C. Coolbaugh. 1986. Factors influencing spore germination and early gametophyte development in Anemia mexicana and Anemia phyllitidis. Plant Physiology 82(1): 230-235. DOI: https://doi.org/10.1104/pp.82.1.230

Nester, J. E. and M. D. Schedlbauer. 1981. Gametophyte Development in Anemia mexicana Klotzsch. Botanical Gazette 142(2): 242-250. DOI: https://doi.org/10.1086/337219

Nester, J. E., S. Veysey and R. C. Coolbaugh. 1987. Partial characterization of an antheridiogen of Anemia mexicana: Comparison with the antheridiogen of $A$. phyllitidis. Planta 170: 26-33. DOI: https://doi.org/10.1007/BF00392377

Pinto, S. C., G. G. Leitão, A. Castellar, D. S. D’Elia, C. L. Lage, A. B. Henriques, J. Fernandes, G. S. Motta, H. R. Bizzo and S. G. Leitão. 2013. Chemical composition of the volatile fractions from wild and in vitro plants of Anemia tomentosa var. anthriscifolia (Pteridophyta). Journal of Essential Oil Research 25(3): 198-202. DOI: https://doi.org/10.1080/10 412905.2012 .755477 
PPG I. 2016. A community-based classification for extant ferns and lycophytes. Journal of Systematics and Evolution 54(6): 563-603. DOI: https://doi.org/10.1111/jse.12229

Pray, T. R. 1971. The gametophyte of Anemia colimensis. American Journal of Botany 58(4): 323-328. DOI: https://doi. org/10.1002/j.1537-2197.1971.tb09980.x

Raghavan, V. and C. S. Huckaby. 1980. A comparative study of cell division patterns during germination of spores of Anemia, Lygodium and Mohria (Schizaeaceae). American Journal of Botany 67(5): 653-663. DOI: https://doi. org/10.1002/j.1537-2197.1980.tb07696.x

Raghavan, V. 1989. Developmental biology of fern gametophytes. Cambridge University Press. Cambridge, UK. Pp. 362.

Ramos Giacosa, J. P. 2014. Abnormal spore morphology and wall ultrastructure in Anemia tomentosa var. anthriscifolia and A. tomentosa var. tomentosa (Anemiaceae). Plant Systematics and Evolution 300: 1571-1578. DOI: https://doi. org/10.1007/s00606-014-0983-2

Ramos Giacosa, J. P., M. A. Morbelli and G. E. Giudice. 2012. Spore morphology and wall ultrastructure of Anemia Swartz species (Anemiaceae) from Argentina. Review of Palaeobotany and Palynology 174: 27-38. DOI: https://doi.org/10.1016/j. revpalbo.2012.02.004

Reynolds, T. L. 1979. Apical dominance in Anemia phyllitidis gametophytes. American Fern Journal 69(3): 92-94. DOI: https://doi.org/10.2307/1546388
Smith, A. R. and M. Kessler. 2017. Prodromus of a fern flora for Bolivia. XIII. Anemiaceae. Phytotaxa 329(1): 080-086. DOI: https://doi.org/10.11646/phytotaxa.329.1.5

Smith, A. R., K. M. Pryer, E. Schuettpelz, P. Korall, H. Schneider and P. G. Wolf. 2006. A classification for extant ferns. Taxon 55(3): 705-731. DOI: https://doi.org/10.2307/25065646

Takahashi, N., C. Kami, N. Morita and R. Imaichi. 2012. Comparative development of heavily asymmetric-cordate gametophytes of Anemia phyllitidis (Anemiaceae) focusing on meristem behavior. Journal of Plant Research 125: 371-380. DOI: https://doi.org/10.1007/s10265-011-0453-7

Thiers, B. 2018 continuously updated. Index Herbariorum: A global directory of public herbaria and associated staff. New York Botanical Garden's Virtual Herbarium. New York, USA. http://sweetgum.nybg.org/ih/ (consulted April, 2018).

Tryon, A. F. and B. Lugardon. 1991. Spores of pteridophytes. Springer. New York, USA. Pp. 107-113.

Von Aderkas, P. and E. G. Cutrer. 1983. Gametophyte plasticity and its bearing on sex expression in Todea barbara (L.) Moore. Botanical Gazette 144(4): 525-532. DOI: https://doi. org/10.1086/337406

Yamane, H. 1998. Fern Antheridiogens. International Review of Cytology 184: 1-32. DOI: https://doi.org/10.1016/S00747696(08)62177-4 